\title{
Lech Mażewski, Długa dekada lat siedemdziesiątych (1968- -1981). Rola nowelizacji z 10 lutego 1976 r. Konstytucji PRL $z 22$ lipca 1952 r. w ewolucji ustroju PRL na tle konstytucji europejskich państw socjalistycznych, Wydawnictwo Adam Marszałek, Toruń 2011, 367 stron
}

Tendencje ustrojowe państw bloku wschodniego, począwszy od lat sześćdziesiątych, szły w kierunku wprowadzania do ustaw zasadniczych przepisu o wejściu państwa w etap socjalizmu, zamykając tym samym okres jego budowy. W przeszłość odchodziły ideologiczne aspekty walki z jego przedwojennym, burżuazyjnym charakterem. Wszystkie państwa satelickie Związku Radzieckiego, w okresie drugiej fali socjalistycznych przemian ustrojowych 1960-1976'1, zadeklarowały w swych konstytucjach zwycięstwo socjalizmu. Zmiany we wszystkich ustawach zasadniczych polegały na wprowadzeniu regulacji o przewodniej lub kierowniczej roli partii i relacji z ZSRR oraz nadaniu państwowości przymiotu socjalistycznego. Oprócz tej ogólnej tendencji poszczególne konstytucje państw socjalistycznych wykazywały pewne odrębności wynikające ze specyfiki wewnętrznej i sytuacji społeczno-politycznej.

Autor $^{2} \mathrm{w}$ recenzowanej książce podjął próbę przedstawienia ewolucji ustroju PRL w kierunku, o którym pisałem na wstępie, oraz odrębności, jakimi charakteryzowała się nowela konstytucyjna z 10 lutego 1976 r. na tle konstytucji europejskich państw socjalistycznych. Rozważania ustrojowo-prawne zamyka w przedziale czasowym lat 1968-1981, proponując nazwać prezentowany okres mianem „długiej dekady lat siedemdziesiątych”. Odrzuca tym samym powszechnie przyjętą periodyzację okresu PRL i próbuje wykazać szczególne powiązania pomiędzy kryzysem lat 1968-1970/71, zmianami ustrojowymi z połowy lat siedemdziesiątych i okresem stanu wojennego, ze szczególnym wskazaniem na rolę nowelizacji konstytucji z 10 lutego 1976 r. Zdaniem autora, daleko idącym skutkiem tej nowelizacji było osłabienie pozycji partii i wzmocnienie roli Rady Ministrów, co pozwoliło Wojciechowi Jaruzelskiemu przejąć kontrolę nad partią i państwem w okresie kryzysu 1980-1981.

Praca usystematyzowana została w siedemnastu rozdziałach, w ramach siedmiu części. W części pierwszej (44 strony, 1 rozdział) ukazana została ewolucja ustrojowa

1 Możemy mówić o dwóch falach konstytucjonalizmu, również w recenzowanej książce istnieje taki podział. Pierwsza fala to konstytucje państw socjalistycznych z lat 1945-1960. Był to powojenny okres budowania zrębów państw socjalistycznych. Druga fala obejmuje lata 1960-1976, w skład której wchodziła nowelizacja Knstytucji PRL z 10 lutego. Były to konstytucje postulujące ugruntowanie socjalizmu.

2 Dr hab. Lech Mażewski - pracownik samodzielny w Katedrze Historii Państwa i Prawa Uniwersytetu Warmińsko-Mazurskiego. Poseł na Sejm I kadencji, z ramienia partii konserwatywnej (25 listopada 1991 - 31 maja 1993 r.). Z ostatnich publikacji wymienić należy: Posttotalitarny autorytaryzm PRL 1956-1989, Arte, Klub Zachowawczo-Monarchistyczny, Warszawa - Biała Podlaska 2010; Stany nadzwyczajne w Polsce w latach 1918-1989: szkic ustrojowopolityczny, Wydawnictwo Adam Marszałek, Toruń 2006; Niszczacy dualizm: polityka NSZZ „Solidarnośc” w latach 1980-1982, Wydawnictwo Adam Marszałek, 2004; Powstańczy szantaż: od konfederacji barskiej do stanu wojennego, Elbląska Oficyna Wydawnicza, Elbląg 2001. 
europejskich państw socjalistycznych, z wyłączeniem Polski Ludowej. Kompleksowej analizie poddane zostały międzywojenne konstytucje ZSRR, leninowskie z 1918 i 1922 oraz stalinowska z 1936 r., stanowiące wzór dla rozwiązań ustrojowych w państwach satelickich. Następnie konstytucje państw objętych wpływami ZSRR, w podziale na pierwszą falę konstytucjonalizmu powojennego budujących się państw socjalistycznych oraz drugą falę konstytucji deklarujących osiągnięcie socjalizmu. Przegląd ewolucji ustrojowej w europejskich państwach socjalistycznych zwieńcza omówienie Konstytucji ZSRR z 1977 r.

Część drugą (54 strony, 3 rozdziały) autor rozpoczyna od przedstawienia postulatów ustrojowych protestujących w latach 1968 i 1970/71 studentów i robotników. W rozdziale 3 przedstawia zapowiedź zmian ustrojowych na VI Zjeździe PZPR, skupiając uwagę na nieścisłości pomiędzy wytycznymi i uchwałą zjazdu a referatem programowym wygłoszonym przez I sekretarza E. Gierka ${ }^{3}$. Następnie omówione zostały postulaty ustrojowe środowiska prawniczego. Część drugą kończy obszerne omówienie reformy administracyjno-terytorialnej z lat 1972-1975, wprowadzenie dwustopniowego podziału terytorialnego i reformy rad narodowych. Nadmienić należy, iż na początku rozdziału 3 (s. 81) autor zawarł niezwykle trafne spostrzeżenie co do ustroju i roli konstytucji w PRL, wynikające z przedstawionej wypowiedzi J. Tejchmy na posiedzeniu Biura Politycznego. Faktycznie konstytucja była jedynie koniecznym aktem państwowotwórczym, powołującym jego naczelne organy, które służyły jedynie legitymizacji władzy PZPR. Nie można jednak zgodzić się z twierdzeniem autora zawartym w przypisie (nr 3) do niniejszego spostrzeżenia. Autor twierdzi, iż aparat państwowy stał się konkurentem partii, który następnie pozbawił ją efektywnej władzy. Aparat państwowy realizował decyzje podejmowane przez Biuro Polityczne PZPR, był całkowicie opanowany przez członków partii, związanych dyscypliną partyjną i nie mogło być mowy o żadnym współzawodnictwie pomiędzy partią a aparatem państwowym. Aparat państwowy był w rzeczywistości aparatem partii.

W części trzeciej (60 stron, 3 rozdziały; od strony 121!) autor przechodzi do meritum rozważań i podejmuje kwestię przygotowania i uchwalenia noweli konstytucyjnej z 1976 r. Rozdział 5 miał ukazać niezwykle ważną kwestię dyskusji w gremiach partyjnych o zmianie Konstytucji PRL. Autor opiera się w nim na spisanych wspomnieniach J. Tejchmy i M. F. Rakowskiego, czy publikacji A. Friszke. Poświęca tej kwestii niecałe 6 stron swojej pracy (122-127), głównie przedstawia dywagacje na temat propozycji ustanowienia i powierzenia E. Gierkowi godności prezydenta. Nie ma jednak stanowiska Biura Politycznego KC PZPR, sprawującego faktyczną władzę w PRL. Brak jest opracowań, notatek czy informacji wydziału administracyjnego KC PZPR na temat nowelizacji konstytucji. Czy takich dokumentów nie ma? Czy przygotowany przez Komisję Nadzwyczajną projekt ustawy o zmianie Konstytucji PRL nie był przedmiotem posiedzenia Biura Politycznego KC PZPR? Materiały źródłowe z posiedzeń organów partii są skarbnicą wiedzy na temat okresu PRL, gdyż tylko odkryte poufne, tajne dokumenty partyjne przechowywane w Archiwum Akt Nowych mogą stanowić prawdziwy wyznacznik dyskusji o kształcie nowelizacji Konstytucji PRL. Tego typu dokumenty przedstawiają realne

3 W wytycznych i uchwale zjazdu była mowa o projekcie nowej konstytucji, zaś E. Gierek, przedstawiając referat Biura Politycznego, mówił o dokonaniu niezbędnych zmian w konstytucji. 
zamiary władzy. Dzienniki, monografie czy publikacje nie posiadają tak wysokiej rangi poznawczej. Także materiały i dokumenty ze zjazdów i plenów PZPR nie odzwierciedlają w pełni stanowiska partii. Miały one głównie charakter propagandowy, nie ukazywały zamierzeń partii, które mogłyby okazać się społecznie niepopularne. Zgrabnie tuszowały te zamierzenia swoją ogólnikowością i pochwałą linii politycznej partii.

W rozdziale 6 części trzeciej omówione zostały wszystkie zmiany nanoszone przez nowelizację do Konstytucji z 22 lipca 1952 r. W szczególności przepisy mówiące, iż Polska Rzeczpospolita Ludowa jest państwem socjalistycznym, z przewodnią rolą partii, umacniającym przyjaźń i współpracę z ZSRR.

W podrozdziale 4 autor pisze o wzmocnieniu pozycji Rady Ministrów poprzez wprowadzenie przepisu o kierowaniu jej pracami przez Prezesa Rady Ministrów. Przepis ten miał charakter czysto deklaratoryjny, gdyż premier jako przewodniczący Rady Ministrów kierował pracami rządu, bez względu na wcześniejszy brak ukonstytuowania tej funkcji. Wypełniono w ten sposób lukę prawną. Zdaniem autora wzmocnieniem kompetencji Prezesa Rady Ministrów było nadanie mu w noweli uprawnienia do wydawania rozporządzeń i zarządzeń, jednak sam autor przypomina w dalszej części, iż premier posiadał już takie kompetencje przed nowelizacją. Był to więc kolejny przepis o charakterze czysto deklaratoryjnym i nie przekazywał Prezesowi Rady Ministrów nowych uprawnień. W tym świetle, niezrozumiałe jest twierdzenie o tak znacznym wzmocnieniu pozycji Prezesa Rady Ministrów w noweli konstytucyjnej. Jedynym nowym uprawnieniem było powierzenie rządowi nadzoru nad NIK, które już po 4 latach zostało przywrócone Sejmowi ${ }^{4}$. Na koniec postawione zostało pytanie: „jak długo tak wzmocniony rząd będzie znosił podporządkowanie kierowniczym instancjom partyjnym PZPR?”. Pomijając fakt, iż rząd faktycznie nie został wzmocniony, a jedynie uzupełniono luki prawne w tekście konstytucji, należy w tym miejscu przypomnieć, iż Prezesem Rady Ministrów w okresie nowelizacji, jak i po, był zawsze członek Biura Politycznego KC PZPR. Ponadto, skład Rady Ministrów podlegał akceptacji Biura. Rząd był jedynie narzędziem realizacji władzy partii. Jakakolwiek niesubordynacja Prezesa Rady Ministrów oznaczałaby koniec kariery politycznej osoby pełniącej tę funkcję i wykluczenie jej z kierownictwa partii.

Autor uważa również, iż osłabiona została rola Sejmu (podrozdział 5). Przeczą temu jego dalsze ustalenia. Przyznanie kompetencji do udzielania rządowi absolutorium z wykonania budżetu wzmacniało pozycję Sejmu, osłabiając jednocześnie pozycję rządu. Przed nowelizacją Sejm mógł jedynie przedstawiać NIK uwagi o wykonywaniu budżetu. Ponadto, wpisano kolejny przepis o charakterze deklaratoryjnym, dotyczący wyznaczania przez Sejm podstawowych kierunków działania państwa.

W podrozdziale 8 Wzmocnienie niezawisłości sędziowskiej, autor stwierdza, iż zastąpienie zasady wybieralności sędziów zasadą ich powoływania wzmocniło niezawisłość sędziowską. Następnie zauważa, iż zasada wybieralności nigdy nie była stosowana, sędziowie byli powoływani, zaś nowelizacja usunęła jedynie martwy przepis. Nowela nie wzmocniła więc niezawisłości sędziowskiej, która notabene była również konstytucyjną fikcją prawną.

Część czwarta (40 stron, 2 rozdziały) stanowi zestawienie rozwiązań ustrojowych wprowadzanych w latach 1960-1977 w europejskich państwach socjalistycznych,

4 Ustawa z 8 października 1980 r. o zmianie Konstytucji PRL (Dz. U. z 1980 r. Nr 22, poz. 81). 
o których traktuje część pierwsza, z rozwiązaniami zawartymi w noweli konstytucyjnej z 1976 r. Jak już zauważyłem na wstępie - podkreślił to również autor - nowelizacje i konstytucje tego okresu kierowały się tendencją zadeklarowania przejścia od okresu budowy do okresu państwa socjalistycznego, ukonstytuowania roli partii oraz relacji z ZSRR. Na tym tle nowelizacja wypełniła więc swoją rolę.

W części piątej (34 strony, 3 rozdziały) przedstawione zostało stanowisko opozycji politycznej wobec noweli lutowej. Rozdział 11 poświęcony został stanowisku Kościoła, sprzeciwiającego się ateizacji życia publicznego. Episkopatowi przypisana została znaczna rola, jaką miał on odegrać w częściowym wycofaniu się przez władzę z planowanych zmian konstytucyjnych. Z książki nie dowiadujemy się jednak, jakie były to ustępstwa. Brakuje w tym miejscu dokumentów partyjnych potwierdzających istnienie rozwiązań, o których dyskutowano, a z których partia się wycofała. Z wcześniejszych rozważań wynika, iż partia porzuciła jedynie pomysł powołania godności Prezydenta PRL. Czy faktycznie władza porzuciła część rozważanych przez siebie rozwiązań pod wpływem postulatów Kościoła i opozycji? Niestety, w tej części, jak również w przedstawionej $\mathrm{w}$ rozdziale 5 części trzeciej debaty nad nowelizacją w gremiach partyjnych, nie mamy informacji na temat jakichkolwiek ustępstw na rzecz postulatów społecznych ani faktów podejmowania przez partię dyskusji pod wpływem ustrojowych programów opozycji.

W części szóstej (40 stron, 3 rozdziały) przedstawione zostały przemiany o charakterze ustrojowo-społecznym, zachodzące w PRL w latach 1976-1981. Tytuł tej części, Uzupetnienia i zmiany znowelizowanej 10 lutego 1976 r. Konstytucji PRL, jest jednak nieadekwatny do jej treści. W latach 1976-1981 jedyna nowelizacja konstytucji miała miejsce 8 października 1980 r. W jej ramach przywrócono kontrolę Sejmu nad NIK, odbierając tę kompetencję Radzie Ministrów. Poza tym, niniejsza część traktuje o powołaniu Naczelnego Sądu Administracyjnego i jego ogromnym znaczeniu w relacjach państwo-obywatel, ograniczającym samowolę urzędniczą; o zmianach w regulaminie Sejmu, o przyjęciu ustawy o przedsiębiorstwach państwowych i samorządzie załogi przedsiębiorstwa. Przedstawiona została również geneza i treść porozumień sierpniowych zawartych pomiędzy PZPR a Międzyzakładowymi Komitetami Strajkowymi, które pozwoliły organizować się społeczeństwu w związkach zawodowych. Autor słusznie zauważył, iż zbliżyło to treść konstytucji do rzeczywistości ustrojowej, gdyż fikcja sprawowania władzy w państwie przez lud pracujący miast i wsi nabierała realnego kształtu. NSZZ „Solidarność” była bowiem platformą, dzięki której społeczeństwo mogło wyrazić swoją wolę. Należy jednak pamiętać, iż związki zawodowe musiały respektować kierowniczą rolę partii oraz nie mogły kwestionować ustroju państwowego opartego na Konstytucji PRL. Poza wskazaną wyżej regulacją kontroli nad NIK, pozostałe kwestie nie znalazły jednak miejsca w ustawie zasadniczej. Przemiany te, choć bardzo doniosłe i mające wpływ na rzeczywistość ustrojową państwa, nie skutkowały wprowadzeniem zmian w ustawie zasadniczej, dlatego nie możemy mówić o uzupełnieniach i zmianach konstytucji. Bardziej adekwatne byłoby określenie: przemiany ustrojowo-społeczne.

Ostatnią część (24 strony, 2 rozdziały) otwiera rozdział 16, w którym przedstawione zostały dwie koncepcje ustrojowe - program obozu władzy wypracowany przez PZPR na IX Nadzwyczajnym Zjeździe, respektujący uchwały XII Kongresu Stronnictwa Demokratycznego oraz opozycyjny program społecznych reform I Krajowego Zjazdu Delegatów NSZZ „Solidarność”. Na koniec autor podejmuje kwestię ustrojowych skutków stanu wojennego, upatrując znaczącego osłabienia władzy Biura Politycznego, wynikającego 
z przerostu nad partią kontrolowanego dotychczas przez nią rządu, a co za tym idzie, przejęcia władzy w państwie przez dyrektoriat z gen. Wojciechem Jaruzelskim na czele.

W podsumowaniu autor stwierdza, iż reforma rad narodowych i nowelizacja konstytucji z 1976 r. zapoczątkowały proces usuwania dominacji w ramach węzła partia- państwo, czego kulminacją była utrata władzy przez Biuro Polityczne KC PZPR w okresie stanu wojennego.

Nowelizacja konstytucji z 1976 r. była aktem niewnoszącym większych zmian w ustroju PRL, nie miała tak donośnych skutków, jakich dopatruje się autor. Nie osłabiła ona dominującej pozycji Biura Politycznego wobec organów państwowych, o czym świadczą dokumenty z jego posiedzeń ${ }^{5}$. Na tle konstytucji europejskich państw socjalistycznych nowelizacja służyła jedynie wypełnieniu ówczesnych tendencji ustrojowych, o których pisałem na wstępie. Uzupełniała luki prawne poprzez deklaratywne wpisanie w treść Konstytucji z 22 lipca 1952 r. rozwiązań już funkcjonujących. Usuwała również niektóre fikcje prawne. Autor pisze o tym, jednak na potrzeby postawionej teorii o daleko idących skutkach nowelizacji, nie zwraca na ten fakt uwagi i błędnie interpretuje zmiany ustrojowe. Nowelizacja nie wzmacniała bowiem roli Rady Ministrów. Jedyne nowe uprawnienie rządu polegające na kontrolowaniu NIK, zostało odebrane nowelizacją z 8 października 1980 r. Ponadto, osłabienie władzy partii na początku lat osiemdziesiątych nie wynikało ze zmiany przepisów ustrojowych. Wydarzenia sierpniowe $1980 \mathrm{r}$., prowadzące w konsekwencji do powstania opozycji wobec PZPR, oddania władzy w ręce gen. Wojciecha Jaruzelskiego i wprowadzenia stanu wojennego były powodem kryzysu gospodarczego. Oczywiście kryzys ten był wynikiem polityki ekipy Gierka, jednak zmiany ustrojowe nie miały praktycznie żadnego wpływu na te wydarzenia. Przejęcie władzy przez gen. Wojciecha Jaruzelskiego nie było również konsekwencją wzmocnienia pozycji Prezesa Rady Ministrów w latach siedemdziesiątych, tym bardziej, iż ta rola została wręcz osłabiona na rzecz Sejmu. Była skutkiem nabrzmiałego kryzysu, z którym partia mogła sobie poradzić jedynie pod silnym przywództwem. Dlatego też, Biuro Polityczne przekazało, za cichym przyzwoleniem, tak szerokie kompetencje gen. Wojciechowi Jaruzelskiemu, który został I sekretarzem partii. Wojskowa Rada Ocalenia Narodowego nie przejęła władzy od Biura Politycznego, nie wystąpiła przeciwko partii, została powołana w celu koordynacji działań paramilitarnych w okresie stanu wojennego i służyła ustabilizowaniu władzy partii w państwie. Po zakończeniu stanu wojennego WRON została rozwiązana, a hegemoniczna pozycja Biura Politycznego KC PZPR została w pełni przywrócona. Twierdzenie autora o upadku władzy partii i przejęciu kontroli przez ośrodek kierowniczy skupiony wokół Wojciecha Jaruzelskiego jest więc niesłuszne. Ośrodek ten

5 Biuro Polityczne decydowało o całokształcie polityki kadrowej w najwyższych organach władzy państwowej. Jej akceptacji podlegał skład Rady Państwa i Rady Ministrów oraz skład Prezydium Sejmu, a także poszczególnych komisji sejmowych. Ponadto, kierowało pracami organów, decydując nie tylko o kierunkach ich działalności, czy wydając zgodę na przyjęcie ustawy, wskazywało nawet wytyczne co do porządku obrad Sejmu, zob. Notatka w sprawie XXVIII posiedzenia Sejmu PRL - stanowiąca materiał na posiedzenie Biura Politycznego KC PZPR w dniu 15 stycznia 1980 r. Archiwum Akt Nowych w Warszawie (dalej: AAN), Polska Zjednoczona Partia Robotnicza. Komitet Centralny w Warszawie 1354 (dalej: KC PZPR 1354), sygn. V/156, s. 233-235; Protokół Nr 4 z posiedzenia Biura Politycznego KC PZPR w dniu 31 marca 1980 r., AAN, KC PZPR 1354, sygn. V/157, s. $432-434$ i $437-443$. 
nigdy nie wystąpił przeciwko PZPR, wręcz przeciwnie, służył ratowaniu pozycji partii i dominacji Biura Politycznego.

W recenzowanej książce można dopatrzeć się dualizmu tematycznego. Pierwsza problematyka dotyczy Długiej dekady lat siedemdziesiątych, stanowiącej próbę wykazania, iż zmiany we władzach partii związane z powstaniem NSZZ „Solidarnośćc i stanem wojennym miały swoje korzenie w wystąpieniach studencko-robotniczych z lat 1968-1970/71. Drugie zagadnienie, podporządkowane pierwszemu, dotyczy przedstawienia roli nowelizacji z 10 lutego 1976 r. Konstytucji PRL z 22 lipca 1952 r. w ewolucji ustroju PRL na tle konstytucji europejskich państw socjalistycznych. Obydwa tematy nie łączą się ze sobą w spójną całość, co prowadzi do mylnej interpretacji przemian ustrojowych zachodzących w latach siedemdziesiątych. Nowelizacja konstytucji nie była wynikiem kryzysu 1968-1971 i nie miała wpływu na strajki z 1980 r. W pierwszym temacie powstaje więc dziesięcioletnia luka i brak logicznych powiązań między wystąpieniami społecznymi. Zaś podporządkowany teorii długiej dekady lat siedemdziesiątych temat nowelizacji konstytucji z 1976 r. został opracowany w sposób niewystarczający, a samej nowelizacji została nadana rola, której ona nie odegrała. Ponadto, brak szerszego spojrzenia na problematykę jej genezy. Autor nie powołuje się na dokumenty Biura Politycznego KC PZPR. Niewiele miejsca poświęca na przedstawienie koncepcji partii. Należy zaznaczyć również, iż na tle ewolucji ustrojowej innych państw socjalistycznych nie została przedstawiona ewolucja ustrojowa PRL.

Na skutek podporządkowania tematu roli nowelizacji z 10 lutego $1976 \mathrm{r}$. Konstytucji PRL z 22 lipca 1952 r. w ewolucji ustroju PRL na tle konstytucji europejskich państw socjalistycznych teorii długiej dekady lat siedemdziesiątych, książka jest niespójna tematycznie, nie przedstawia faktycznej roli nowelizacji i umiejscawia ją w zbyt szerokim kontekście historycznym.

Obowiązkiem recenzenta jest krytyczne spojrzenie na treść książki, rzetelność i sposób przedstawienia podejmowanego przez autora tematu, stąd powyższe uwagi. Zachowując jednak obiektywizm należy nadmienić, iż książka stanowi krok naprzód w rozwoju nauk historyczno-prawnych. Zawiera w sobie szerokie spojrzenie na problematykę ustrojowo-prawną, system sprawowania władzy przez PZPR i wpływ wydarzeń o charakterze społecznym na zmianę kierunków polityki partii i kształtu państwa. Recenzowana książka może stanowić wstęp do rzeczowej dyskusji na temat roli konstytucji i ewolucji mechanizmów sprawowania władzy w Polsce Ludowej. 